\title{
Pyrrolizidine Alkaloids from Heliotropium indicum
}

\author{
João Sammy N. Souza ${ }^{a}$, Luciana L. Machado ${ }^{a}$, Otília D. L. Pessoa ${ }^{a}$, Raimundo Braz-Filho ${ }^{b}$, \\ Cassia R. Overk, Ping Yao ${ }^{c}$, Geoffrey A. Cordell ${ }^{c}$ and Telma L. G. Lemos ${ }^{*, a}$ \\ ${ }^{a}$ Departamento de Química Orgânica e Inorgânica, Universidade Federal do Ceará, 12451-970 \\ Fortaleza-CE, Brazil \\ ${ }^{b}$ Setor de Química de Produtos Naturais - LCQUI - CCT, Universidade Estadual do Norte Fluminense, \\ Campos - RJ, Brazil \\ ${ }^{c}$ Department of Medicinal Chemistry and Pharmacognosy, College of Pharmacy, University of Illinois at Chicago, \\ Chicago, Il 60612, USA
}

\begin{abstract}
Um novo alcalóide denominado Helindicina (1), e o conhecido licopsamina (2) foram isolados das raízes de Heliotropium indicum (Boraginaceae). As estruturas foram estabelecidas tendo como base um amplo estudo de 1D e 2D RMN (COSY, HMBC, HMQC, NOESY) e HREIMS. Este representa o primeiro relato de um alcalóide contendo um anel lacônico no gênero Heliotropium. Estes alcalóides mostraram moderada atividade antioxidante.
\end{abstract}

Helindicine (1), a new pyrrolizidine alkaloid with unusual structural features, together with the known lycopsamine (2), were isolated from the roots of Heliotropium indicum (Boraginaceae). The structures were established by a combination of 1D and 2D NMR methods (COSY, HMQC, HMBC, and NOESY) and HREIMS. This is the first report of a lactone pyrrolizidine alkaloid in the genus Heliotropium. Compounds $\mathbf{1}$ and $\mathbf{2}$ were assayed for antioxidant activity and showed moderate activity.

Keywords: Heliotropium indicum, Boraginaceae, pyrrolizidine alkaloids, antioxidant activity

\section{Introduction}

Pyrrolizidine alkaloids are considered of great pharmacological, biological and chemotaxonomic interest. ${ }^{1-3}$ These metabolites have been isolated from a wide variety of plants, especially from genera belonging to the Boraginaceae family. ${ }^{46}$ The genus Heliotropium, a well-known source of such alkaloids ${ }^{7-9}$ and other minor compounds, such as flavonoids and geranyl aromatic derivatives, is constituted of about 250 species represented by herbs and shrubs, distributed throughout the terrestrial globe. ${ }^{10}$

In the course of a search for novel and biologically active compounds from plants the EtOH extract from the roots of Heliotropium indicum L., popularly known as fedegoso, found abundantly in the region of northeast Brazil, was investigated. This species is widely used in folk medicine in the treatment of skin disease, and as a powerful expectorant. ${ }^{11}$ Based on a literature survey, the investigated species has been the subject

\footnotetext{
* e-mail: tlemos@dqoi.ufc.br
}

of several previous studies, leading to the isolation of pyrrolizidine alkaloids. ${ }^{3,12}$ This paper describes the isolation and structure elucidation of the new pyrrolizidine alkaloid 1, and the known alkaloid lycopsamine (2).

\section{Results and Discussion}

Alkaloid 1 was isolated as a colorless oil. Its molecular formula of $\mathrm{C}_{15} \mathrm{H}_{23} \mathrm{NO}_{4}$, was deduced by HR-EIMS $(\mathrm{m} / \mathrm{z}$ 281.1627, $\mathrm{M}^{+}$). The IR spectrum exhibited characteristic absorptions of hydroxyl and carbonyl groups at $v_{\max } 3435$ and $1726 \mathrm{~cm}^{-1}$, respectively. Its EI-MS gave a molecular ion peak at $\mathrm{m} / \mathrm{z} 281$, and a base peak at $\mathrm{m} / \mathrm{z} 207$ (1a, $\mathrm{C}_{11} \mathrm{H}_{13} \mathrm{NO}_{3}$ ), along with unusual PA fragmentation ions at $\mathrm{m} / \mathrm{z} 149$ (1b, 37\%, $\left.\mathrm{C}_{9} \mathrm{H}_{11} \mathrm{NO}\right), 135$ (1c, 33\%, $\left.\mathrm{C}_{8} \mathrm{H}_{9} \mathrm{NO}\right)$, $115\left(\mathbf{1 d}, 15 \%, \mathrm{C}_{6} \mathrm{H}_{11} \mathrm{O}_{2}\right), 109\left(\mathbf{1 e}, 34 \%, \mathrm{C}_{7} \mathrm{H}_{11} \mathrm{~N}\right), 95$ (1f, $\left.55 \%, \mathrm{C}_{6} \mathrm{H}_{9} \mathrm{~N}\right)$ and $81\left(\mathbf{1 g}, 46 \%, \mathrm{C}_{5} \mathrm{H}_{7} \mathrm{~N}\right)$, compatible with the proposed structure (Figure 1).

The ${ }^{13} \mathrm{C}$ NMR spectrum displayed a total of fifteen carbon signals, while the DEPT experiment evidenced the 
<smiles></smiles>

1a $m / z 207(100 \%)$<smiles>CC1=CCN2CC[C@H](O)[C@H]12</smiles>

$1 \mathrm{~b} m / z 149(37 \%)$<smiles>C=C1C=CN2CCC(=O)[C@H]12</smiles>

$1 \mathrm{c} m / z 135(33 \%)$<smiles>CC(=O)C(=O)C(C)C</smiles>

$1 \mathrm{~d} m / z 115(15 \%)$<smiles>[CH2]C1=CC[N+](CC)=C1</smiles>

1e $m / z 109(34 \%)$<smiles></smiles>

1f $m / z 95(55 \%)$<smiles>[CH2]C1=CC[NH+]([CH2+])C1</smiles>

$\lg m / z 81(46 \%)$

Figure 1. Fragments proposed to justify peaks observed in the mass spectrum of $\mathbf{1}$.

presence of three methyls, four methylenes and five methines, and consequently, three quaternary carbon atoms. The ${ }^{1} \mathrm{H}$ NMR spectrum of $\mathbf{1}$ exhibited signals at $\delta_{\mathrm{H}} 0.93(\mathrm{~d}$, $J 7.0 \mathrm{~Hz}, \mathrm{H}_{3}-7^{\prime}$ ), 0.95 (d, J 7.0 Hz, $\mathrm{H}_{3}-6^{\prime}$ ), and 2.03 (hept, $J 7.0 \mathrm{~Hz}, \mathrm{H}-5$ '), characteristic of an isopropyl group, along with an oxymethine group, showing a resonance at $\delta_{\mathrm{H}} 4.05$ (q, $J 6.2 \mathrm{~Hz}, \mathrm{H}-3^{\prime}$ ) and an additional methyl signal at $\delta_{\mathrm{H}}$ 1.17 (d, $J 6.2 \mathrm{~Hz}, \mathrm{H}_{3}-4^{\prime}$ ). These hydrogen signals were correlated with the carbon signals at $\delta_{\mathrm{C}} 17.6\left(\mathrm{CH}_{3}-7^{\prime}\right), 17.2$ ( $\left.\mathrm{CH}_{3}-6^{\prime}\right), 34.2$ (CH-5'), 70.5 (CH-3'), and $17.3\left(\mathrm{CH}_{3}-4^{\prime}\right)$, respectively, in the HMQC spectrum. Both $\mathrm{H}-3$ ' and $\mathrm{H}-5$ ' displayed ${ }^{3} J$-HMBC correlations with the ester carbonyl group at $\delta_{\mathrm{C}} 175.6\left(\mathrm{C}-1^{\prime}\right)$. These data are in agreement with a viridiflorate ester moiety. ${ }^{13-15} \mathrm{~A}$ deshielded hydrogen signal at $\delta_{\mathrm{H}} 5.94(\mathrm{~s}, \mathrm{H}-2)$ in the ${ }^{1} \mathrm{H}$ NMR spectrum, together with two olefinic carbon signals at $\delta_{\mathrm{C}} 125.3(\mathrm{CH}-2)$ and 134.2 (C-1), suggested the presence of a trisubstituted double bond. Signals assigned to oxygenated carbon atoms were observed at $\delta_{\mathrm{H}} 70.5(\mathrm{CH}-7)$ and $61.7\left(\mathrm{CH}_{2}-9\right)$, which showed correlations with the hydrogen signals at $\delta_{\mathrm{H}} 4.63 \mathrm{(br} \mathrm{s}$, H-7) and 4.98 (d, $J 13.8 \mathrm{~Hz}, \mathrm{H}-9 \mathrm{a})$ and 4.80 (d, $J 13.8 \mathrm{~Hz}$, $\mathrm{H}-9 \mathrm{~b})$, respectively. Additionally, signals corresponding to three carbon atoms attached to nitrogen were also observed at $\delta_{\mathrm{C}} 80.5(\mathrm{CH}-8), 62.5\left(\mathrm{CH}_{2}-3\right)$, and $55.5\left(\mathrm{CH}_{2}-5\right)$. These data were all consistent with a retronecine moiety. ${ }^{12-14} \mathrm{As}$ expected, the HMBC spectrum of $\mathbf{1}$ revealed a correlation between $\mathrm{H}-7$ and the oxymethine carbon atom $\mathrm{CH}-3^{\prime}$, as well as a correlation between H-3' and CH-7. The NOESY correlation between the oxymethine hydrogen $\mathrm{H}-7$ and the methyl hydrogens $\mathrm{H}_{3}-4$ ', both in the $a$-position, confirmed this deduction. The relative stereochemistry of $\mathbf{1}$ was established based on coupling constant values and the NOESY experiment (Figure 2).

It is worth noting that helindicine (1) is an unusual 9-membered lactone pyrrolizidine alkaloid, which is formed by an ether linkage between C-3' of the viridiflorate ester side chain and the $\mathrm{C}-7$ of the retronecine moiety. Moreover, this is the first example<smiles>C[C@H]1[C@@H]2CCN3CC=C(COC(=O)[C@]1(O)C(C)(C)C)[C@]3(C)[C@@H](C)O2</smiles><smiles>CC(C)[C@@](O)(C(=O)OCC1=CCN2CC[C@H](O)[C@H]12)C(C)O</smiles>

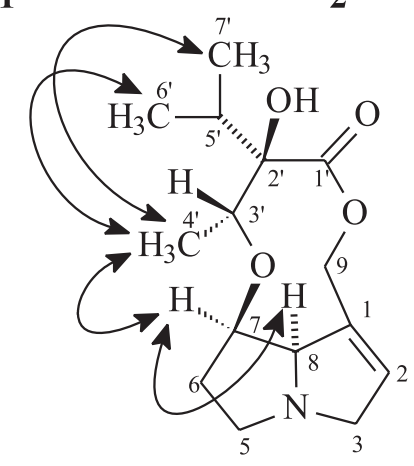

Figure 2. Important NOESY correlations of $\mathbf{1 .}$ 
Table 1. ${ }^{1} \mathrm{H}(400 \mathrm{MHz})$ and ${ }^{13} \mathrm{C}(100 \mathrm{MHz})$ NMR spectral data for helindicine (1) and lycopsamine (2) in $\mathrm{CD}_{3} \mathrm{OD}$ as solvent

\begin{tabular}{|c|c|c|c|c|c|c|}
\hline \multirow[b]{2}{*}{$\mathrm{C}$} & \multirow[b]{2}{*}{$\delta_{\mathrm{C}}$} & \multicolumn{3}{|c|}{1} & \multicolumn{2}{|c|}{2} \\
\hline & & $\delta_{\mathrm{H}}$ & ${ }^{2} J_{\mathrm{CH}}$ & ${ }^{3} J_{\mathrm{CH}}$ & $\delta_{\mathrm{C}}$ & $\delta_{\mathrm{H}}$ \\
\hline 1 & 134.2 & & $\mathrm{H}-2, \mathrm{H}-8$ & & 133.2 & \\
\hline 2 & 125.3 & $5.94(\mathrm{br} \mathrm{s})$ & $2 \mathrm{H}-3, \mathrm{H}-8$ & & 129.7 & 5.87 (br s) \\
\hline \multirow[t]{2}{*}{3} & 62.5 & $4.40(\mathrm{br} \mathrm{d}, J 15.0)$ & H-2 & $\mathrm{H}-5 \mathrm{~b}$ & 62.9 & 3.96 \\
\hline & & $3.92(\mathrm{br} \mathrm{d}, J 15.0)$ & & & & 3.45 \\
\hline \multirow[t]{2}{*}{5} & 55.5 & $3.97(\mathrm{~m})$ & & $2 \mathrm{H}-3$ & 54.1 & $3.36(\mathrm{~m})$ \\
\hline & & $3.34(\mathrm{~m})$ & & & & $2.78(\mathrm{~m})$ \\
\hline 6 & 36.7 & $2.15(2 \mathrm{H}, \mathrm{m})$ & $\mathrm{H}-5 \mathrm{~b}$ & & 36.5 & $1.98(2 \mathrm{H}, \mathrm{m})$ \\
\hline 7 & 70.5 & $4.63(\mathrm{br} \mathrm{s})$ & $2 \mathrm{H}-6$ & $2 \mathrm{H}-5, \mathrm{H}-3$, & 69.6 & 4.33 (br s) \\
\hline 8 & 80.5 & $4.90(\mathrm{br} s)$ & & $\mathrm{H}-2,2 \mathrm{H}-6$ & 78.8 & $4.29(\mathrm{br} \mathrm{s})$ \\
\hline \multirow[t]{2}{*}{9} & 61.7 & $4.98(\mathrm{~d}, J 13.8)$ & & H-2 & 62.8 & $5.09(\mathrm{~d}, J 12.7)$ \\
\hline & & $4.80(\mathrm{~d}, J$ 13.8) & & & & $4.58(\mathrm{~d}, J 12.7)$ \\
\hline 1 ' & 175.6 & & & 2H-9, H-3',H-5' & 175.7 & \\
\hline 2 ' & 84.5 & & $\mathrm{H}-5$, & $3 \mathrm{H}-4,, 3 \mathrm{H}-6$ ', 3H-7' & 83.3 & \\
\hline 3, & 70.5 & $4.05(\mathrm{q}, J 6.2)$ & $3 \mathrm{H}-4$ & H-7 & 71.4 & $4.04(\mathrm{q}, J 6.4)$ \\
\hline 4, & 17.3 & $1.17(\mathrm{~d}, J 6.2)$ & & & 17.5 & $1.16(\mathrm{~d}, J 6.4)$ \\
\hline 5 , & 34.2 & 2.03 (hept. $J 7.0$ ) & 3Н-6', 3Н-7' & & 32.9 & $2.78(\mathrm{~m})$ \\
\hline 6' & 17.2 & $0.95(\mathrm{~d}, J 7.0)$ & H-5 & & 17.1 & $0.93(\mathrm{~d}, J 7.0)$ \\
\hline 7 ' & 17.6 & $0.93(\mathrm{~d}, J 7.0)$ & $\mathrm{H}-5$, & & 17.7 & $0.91(\mathrm{~d}, J 7.0)$ \\
\hline
\end{tabular}

${ }^{a}$ All assignments were based on DEPT, COSY, HMQC, HMBC and NOESY experiments. Coupling constants $(J)$ in Hz for hydrogen atoms were obtained of the 1D ${ }^{1} \mathrm{H}$ NMR spectra. Superimposed ${ }^{1} \mathrm{H}$ signals are described without multiplicity and chemical shifts deduced by HMQC, HMBC and ${ }^{1} \mathrm{H}-{ }^{1} \mathrm{H}-\mathrm{COSY}$ spectra.

of a lactone pyrrolizidine alkaloid isolated from the genus Heliotropium.

The more polar isolated alkaloid was identified as lycopsamine (2), by comparison of its physical and spectral properties with literature data. ${ }^{7,15}$

The results of an extensive application of $1 \mathrm{D}\left({ }^{1} \mathrm{H} N \mathrm{NR}\right.$, proton broad-band decoupled and DEPT- ${ }^{13} \mathrm{C}$ NMR) and 2D $\left({ }^{1} \mathrm{H}-{ }^{1} \mathrm{H}-\mathrm{COSY},{ }^{1} \mathrm{H}-{ }^{-1} \mathrm{H}-\mathrm{NOESY}, \mathrm{HMQC}\right.$ and HMBC) spectral techniques were also used to establish the complete ${ }^{1} \mathrm{H}$ and ${ }^{13} \mathrm{C}$ resonance assignments of these two pyrrolizidine alkaloids (1 and $\mathbf{2}$ ).

Structural examination of the these compounds in view of using biosynthetic arguments and application of a biosynthetic retroanalysis led us to suggest biogenetic route and, consequently, the alkaloid lycopsamine (2) may be postulated as precursor of helindicine (1) through a dehydration reaction. The antioxidant activities of $\mathbf{1}$ and $\mathbf{2}$, together with standard radical scavenging trolox and BHT were tested and compared (Table 2). As can be seen, $\mathbf{1}$ and $\mathbf{2}$ showed moderate free radical scavenging ability. The higher level of lycopsamine (2) as compared to helindicine (1) is probably due to the free hydroxyl group.

Alkaloids $\mathbf{1}$ and $\mathbf{2}$ were also tested for binding to estrogen receptor $\alpha$ and $\beta$, and alkaline phosphatase induction in Ishikawa cells. Neither alkaloid showed activity $(>50 \%)$ in these assays.

\section{Experimental}

\section{General}

The optical rotations were measured on a PerkinElmer 341 digital polarimeter. IR spectra were recorded on a Perkin-Elmer 1000 FT-IR spectrometer. Mass spectra data (EI-MS and HR-EIMS) were acquired on a Shimadzu QP5050A and a JEOL CGMate II instrument, through direct probe and operating at $70 \mathrm{eV}$. NMR

Table 2. The DPPH free radical scavenging activity of alkaloids $\mathbf{1}$ and $\mathbf{2}$. The free radical scavenging effect was measured by the absorbance radical at 520 $\mathrm{nm}$ in a reaction containing the test sample and $60 \mu \mathrm{mol} \mathrm{L}{ }^{-1} \mathrm{DPPH}$

\begin{tabular}{|c|c|c|c|c|c|c|}
\hline \multirow[t]{3}{*}{ Treatment } & & & \multicolumn{4}{|c|}{ Concentration/(mg mL $\left.\mathrm{mL}^{-1}\right)$} \\
\hline & \multicolumn{2}{|c|}{1.0} & \multicolumn{2}{|c|}{0.5} & \multicolumn{2}{|c|}{0.25} \\
\hline & Activity & $\%$ & Activity & $\%$ & Activity & $\%$ \\
\hline 1 & 0.1852 & 36.00 & 0.1925 & 34.00 & 0.1941 & 33.90 \\
\hline 2 & 0.1700 & 42.10 & 0.1727 & 41.02 & 0.1743 & 40.70 \\
\hline Trolox & 0.0110 & 95.60 & 0.0110 & 95.60 & 0.0110 & 95.60 \\
\hline BHT & 0.0824 & 64.00 & 0.0871 & 62.00 & 0.1172 & 48.60 \\
\hline Control & 0.2285 & 00.00 & 0.2285 & 00.00 & 0.2285 & 00.00 \\
\hline
\end{tabular}


experiments were performed on a Bruker DRX-500 $\left[{ }^{1} \mathrm{H}\right.$ $(500 \mathrm{MHz})$ and $\left.{ }^{13} \mathrm{C}(125 \mathrm{MHz})\right]$ and Varian UM-400 $\left[{ }^{1} \mathrm{H}\right.$ $(400 \mathrm{MHz})$ and $\left.{ }^{13} \mathrm{C}(100 \mathrm{MHz})\right]$ spectrometers. Silica gel 60 (70-230 mesh, Merck) and Sephadex LH-20 (Pharmacie) was used for column chromatography. TLC was performed on silica gel sheets over polyethylene (Kieselgel $60 \mathrm{~F}_{254}, 0.20 \mathrm{~mm}$, Merck). Compounds were detected by spraying with Dragendorff's reagent and reaction with iodine vapors.

\section{Plant material}

The roots of $H$. indicum were harvested from Pentecoste County, State of Ceará - Brazil, in January 2003. The plant material was authenticated by Professor Edson P. Nunes, and a voucher specimen (\# 31.610) has been deposited at the Herbário Prisco Bezerra (EAC) of the Departamento de Biologia, Universidade Federal do Ceará.

\section{Extraction and isolation}

Dried and powdered roots of $H$. indicum (1200 g) were exhaustively extracted with $\mathrm{EtOH}$ at room temperature (x $3)$. The combined extracts were evaporated in vacuum to yield a crude extract $(90.0 \mathrm{~g})$, which was processed in the usual way as for alkaloid extraction. ${ }^{16}$ The alkaloid fraction $(10.0 \mathrm{~g})$ was separated on a silica gel column, using $n$ hexane, $\mathrm{CHCl}_{3}$, EtOAc, and $\mathrm{MeOH}$ successively as eluents. The $\mathrm{MeOH}$ fraction $(3.5 \mathrm{~g}$ ) was initially suspended in acetone, and then $\mathrm{MeOH}$. The acetone-soluble fraction (1.1 g) was chromatographed on Si gel using a stepwise gradient solvent system of hexane-EtOAc (1:1), EtOAc, EtOAcacetone $(1: 1)$, acetone, acetone- $\mathrm{MeOH}(1: 1)$, and $\mathrm{MeOH}$ to obtain 10 fractions, each of $50 \mathrm{~mL}$. The fractions were monitored by TLC and pooled into three fractions. Fraction $3(819 \mathrm{mg})$ was rechromatographed on Si gel using EtOAc with increasing amounts of $\mathrm{MeOH}(10-80 \%)$ to yield 4 subfractions. Fraction $1(70 \mathrm{mg})$ was chromatographed on a column of Sephadex LH-20 using $\mathrm{MeOH}$ as eluent to yield $1(64 \mathrm{mg})$. The $\mathrm{MeOH}$-soluble fraction $(589 \mathrm{mg}$ ) was chromatographed on a Si gel column and eluted with a stepwise gradient solvent system of EtOAc-acetone (8:2 to $2: 8$ ) and acetone- $\mathrm{MeOH}$ (8:2 to 8:2) to obtain 36 fractions, which were monitored by TLC and pooled to 10 fractions. The fraction 5, obtained with EtOAc-acetone (7:3), yielded $2(48.5 \mathrm{mg})$.

\section{Identification of the isolated alkaloids}

Helindicine (1). Colorless resin; $[\alpha]_{\mathrm{D}}^{20}-0.64^{\circ}$ (c 0.05 , $\left.\mathrm{CH}_{3} \mathrm{OH}\right)$; IR $\left(\mathrm{CHCl}_{3}\right) v_{\max } / \mathrm{cm}^{-1}: 3435,1726,1636,1244$,
1030; HR-EIMS $\left(\mathrm{M}^{+}, m / z\right.$ 281.2); EI-MS $m / z$ (rel. int.): $281[\mathrm{M}]^{+}$. (35), 207 (100), 191 (15), 149 (37), 135 (33), 109 (34), 97 (73), 95 (55), 83 (57), 81 (46); ${ }^{1} \mathrm{H}$ and ${ }^{13} \mathrm{C}$ NMR ( $\left.\mathrm{CD}_{3} \mathrm{OD}\right)(500$ and $125 \mathrm{MHz}$, respectively) data, see Table 1.

Lycopsamine (2). Colorless resin; $[\alpha]_{\mathrm{D}}^{20}+0.12^{\circ}(c 0.05$, $\left.\mathrm{CHCl}_{3}\right)$; IR $\left(\mathrm{CHCl}_{3}\right) v_{\text {max }} / \mathrm{cm}^{-1}: 3411,1732,1559,1236$, 1022; HR-EIMS ( $\mathbf{M}^{+}, \mathrm{m} / z$ 299.2); EIMS: $m / z 299\left[\mathrm{M}^{+}\right]$ (1.6), 254 (1.5), 156 (13), 138 (100), 120 (15), 108 (5.0), 93 (47), 80 (26); ${ }^{1} \mathrm{H}$ and ${ }^{13} \mathrm{C}$ NMR ( $\left.\mathrm{CD}_{3} \mathrm{OD}\right)$ (500 and 125 $\mathrm{MHz}$, respectively) data, see Table 1 .

\section{DPPH assay}

The antioxidant activities of compounds $\mathbf{1}$ and $\mathbf{2}$ were assessed on the basis of the radical scavenging effect of the stable DPPH free radical. One milliliter of a $60 \mu \mathrm{mol}$ $\mathrm{L}^{-1} \mathrm{DPPH}$ ethanol solution was added to sample solutions at three different concentrations and allowed to react at room temperature. After $30 \mathrm{~min}$, the absorbance values were measured at $520 \mathrm{~nm}$ using a spectrophotometer and converted into the percentage antioxidant activity using a known procedure. ${ }^{17,18}$ Blank experiment were also carried out to determine the absorbance of DPPH before interacting with the compounds. Trolox and BHT were used as positive control compounds.

\section{Acknowledgments}

This work was supported by grants from the Brazilian National Agencies CAPES/CNPq/FUNCAP/PRONEX and FAPERJ.

\section{References}

1. Reddy, J. S.; Rao, R. P.; Reddy, M. S.; J. Ethnopharmacol. 2002, 79, 249.

2. Reina, M.; Gonzalez-Coloma, A.; Gutierrez, C.; Cabrera, R.; Henríquez, J.; Villarroel, L.; Phytochemistry 1998, 46, 845.

3. Catalfamo, J. L.; Martin Jr., W. B.; Birecka, H.; Phytochemistry 1982, 21, 2669.

4. Birecka, H.; Frohlich, M.W.; Hull, L.; Chaskes, M.J.; Phytochemistry 1980, 19, 421.

5. Stermitz, F.R.; Pass, M.A.; Kelley, R.B.; Liddell, J.R.; Phytochemistry 1993, 33, 383.

6. Roeder, E.; Bourauel, T.; Phytochemistry 1992, 31, 3613.

7. Reina, M.; Gonzalez-Colona, A.; Gutierrez, C.; Cabrera, R.; Henríquez, J.; Villarroel, L.; J. Nat. Prod. 1998, 61, 1418.

8. Lakshmanan, A.J.; Shanmugasundaram, S.; Phytochemistry 1995, 39, 473. 
9. Ravi, S.; Lakshmanan, J.; Herz, W.; Phytochemistry 1990, 29 , 361.

10. Villarroel, L.; Torres, R.; Urzúa, A.; Reina, M.; Cabrera, R.; González-Colona, A.; J. Nat. Prod. 2001, 64, 1123.

11. Braga, R.; Plantas do Nordeste, Especialmente do Ceará, $3^{\text {rd }}$ ed., Coleção Mossoroense: RN, 1976, p. 249.

12. Mattocks, A.R.; J. Chem. Soc., (C) 1967, 329.

13. Davicino, J.G.; Pestchanker, M.J.; Giordano, O.S.; Phytochemistry 1988, 27, 960.

14. Kelley, R.B.; Seiber, J.N.; Phytochemistry 1992, 31, 2513.
15. Roeder, E.; Breitmaier, E.; Birecka, H.; Frohlich M.W.; BadziesCrombach, A.; Phytochemistry 1991, 30, 1703.

16. Lemos, T. L. G.; Andrade, C. H. S.; Guimarães, A. M.; WolterFilho, W.; Braz-Filho, R.; J. Braz. Chem. Soc. 1996, 7, 123.

17. Chen, C. H.; Shaw, C. Y.; Chen, C. C.; Tsai, Y. C.; J. Nat. Prod. 2002, 65, 740 .

18. Hegazi, A. G.; El Hady, F. K. A.; Z. Naturforsch., C 2002, 57, 395.

Received: June 6, 2005

Published on the web: November 18, 2005 